\title{
Culture Conditions for Improving Extracellular Lipolytic Enzyme Production by a Novel Thermophilic Geobacillus sp. AR1
}

\author{
Su-Jin Park ${ }^{1}$ and Sung-Jong Jeon ${ }^{1,2} \star$ \\ ${ }^{1}$ Department of Biotechnology \& Bioengineering and ${ }^{2}$ Department of Biomaterial Control (BK21 program), Dong-Eui University, Busan 614-714, \\ Korea
}

Received November 14, 2012 /Revised December 20, 2012 /Accepted January 4, 2013

\begin{abstract}
A microorganism (strain AR1) producing an extracellular lipolytic enzyme was isolated from hot springs located in Beppu, Japan. Phylogenetic analysis based on the 16S rDNA sequence and biochemical studies indicated that AR1 belongs to the genus Geobacillus. This study focused on novel strategies to increase extracellular lipolytic enzyme production by this novel Geobacillus sp. AR1. Cultures of the AR1 strain grew within a wide temperature range (from 35 to $75^{\circ} \mathrm{C}$ ); the optimum temperature was $65^{\circ} \mathrm{C}$. The $\mathrm{pH}$ for optimal growth was 6.5 , whereas the optimum $\mathrm{pH}$ for lipolytic enzyme production was 8.5. The presence of oils in the culture medium led to improvements in lipolytic enzyme activity. Soybean oil was the most efficient inducer, and it yielded better results when added in the exponential phase. On the other hand, the addition of chemical surfactants led to lipolytic enzyme production. Their addition to the culture could affect the location of the enzyme activity. The addition of Tween 20 in the stationary phase significantly increased the proportion of the extracellular enzyme activity. According to the results, following the addition of soybean oil and Tween 20 in the exponential and stationary phases, the extracellular lipolytic activity was increased 2.4-fold compared with that of a control.
\end{abstract}

Key words : Geobacillus, lipolytic enzyme, oil, surfactant

\section{서 론}

지질분해효소(lipolytic enzyme)는 긴 사슬 triacylglycerides 또는 짧은 사슬 fatty acids의 가수분해반응과 합성반 응을 촉매하고[1], 식품, 세제, 펄프 등의 다양한 산업분야에서 이용되고 있다[1, 22]. 미생물에 의한 지질분해효소 생산은 탄 소원, 온도, $\mathrm{pH}$, 산소농도, 및 유도물질과 같은 다양한 요인들 에 의하여 영향을 받는다. 또한 지질 화합물과 몇몇 계면활성 제들은 지질분해효소의 생산 및 활성을 증가시키는 것으로 알려져 있다[20]. 더불어, 미생물 배양조건은 다량의 isoenzyme을 생산하기 위하여 다양한 방법들을 제시하고 있다 [11]. 미생물을 이용한 효소 생산 과정에서 지질분해효소의 생 산량과 균체량과는 서로 간에 상관관계가 있지만, 효소 생산 이 미생물의 생장률과 반드시 비례하지는 않는다[6-8]. 따라 서, 세포 생장과 효소분비를 촉진하는 배양조건(배지 조성, $\mathrm{pH}$, 온도, 산소 농도)에 대해 연구하는 것은 효율적인 효소생 산을 위해 반드시 필요하다. 또한 미생물 세포막의 성질과 투

\section{*Corresponding author}

Tel : +82-51-890-2278, Fax : +82-51-890-2632

E-mail : jeon.sj@deu.ac.kr

This is an Open-Access article distributed under the terms of the Creative Commons Attribution Non-Commercial License (http://creativecommons.org/licenses/by-nc/3.0) which permits unrestricted non-commercial use, distribution, and reproduction in any medium, provided the original work is properly cited.
과성은 막간 공간(periplasmic space)에서 세포 외로 효소 분 비를 조절함에 있어 중대한 영향을 미친다.

최근 내열성 효소는 고온에서 안정할 뿐만 아니라, 중온성 효소에 비해 화학물질과 극한 $\mathrm{pH}$ 조건에서 더 저항성을 가지 기 때문에 이들에 대한 관심이 증가하고 있다. 그러나, 고온성 extracellular 지질분해효소를 생산하는 미생물은 Bacillus megaterium [19], Bacillus thermoamylovorans [4], Staphylococcus sp. [3], 및 Thermus thermophilus [7] 등에 한정되어 있어 더욱 다양 한 미생물에 대한 연구가 필요하다.

본 연구에서는 온천수에서 고온성 extracellular 지질분해 효소의 활성을 나타내는 새로운 Geobacillus sp. AR1균주를 분 리하고, 이 균주의 extracellular 효소 생산을 증가시키기 위한 배양조건의 최적화 및 지질 화합물과 계면활성제의 유도효과 를 연구함으로써 효소 생산을 향상시키고자 하였다.

\section{재료 및 방법}

\section{균주 분리 및 동정}

본 연구에 사용된 Geobacillus sp. AR1 균주는 일본의 $\mathrm{Beppu}$ 온천수에서 분리하였다. 분리방법은 지질분해균 선별 을 위한 기질로 tributyrin을 첨가한 plate assay법[13]을 사용 하였고, 고온균 분리를 위해 $70^{\circ} \mathrm{C}$ 에서 배양하였다. 지질 분해 균 선별 배지에 균을 접종하여 colony 주위에 투명환(clear zone)을 형성하는 것을 지질분해효소 양성균으로 선별하였고, 
이들을 $1 \%$ tributyrin을 첨가한 영양배지 $(0.3 \%$ polypeptone, $0.2 \%$ yeast extract, $0.05 \% \mathrm{NaCl}, 0.02 \% \mathrm{CaCl}_{2} \cdot 2 \mathrm{H}_{2} \mathrm{O}, 0.01 \%$ $\mathrm{MgSO}_{4} \cdot 7 \mathrm{H}_{2} \mathrm{O}$ )에서 배양하여 배양 상등액의 효소활성이 가장 높은 균주를 최종 선별하여 사용하였다. 분리균주의 생리학적 특징은 Santos 등[18]의 방법을 이용하여 조사하였고, $16 \mathrm{~s}$ rRNA sequence분석은 Kim 등[12]의 방법에 따라 실시하였 다.

\section{유도물질의 효과}

유도물질의 효과를 알아보기 위하여 $1 \%$ 의 sesame oil, sunflower oil, soybean oil, grapeseed oil, canola oil, lard oil, olive oil, 및 tributyrin을 배지에 첨가한 후, homogenizer을 이용하여 유화시키고 미생물을 접종하여 24 시간 동안 배양하 였다. 배양된 시료는 균체 중량과 효소 활성측정을 위해 사용 하였다. 또한 높은 유도효과를 가지는 유도물질을 각각 배양 후 $0,5,10$ 시간 만에 첨가하고 24 시간 후에 효소 활성의 변화 를 조사하였다. 몇 가지 계면활성제(Triton X-100, Tween 80, Tween 20, PEG 200)는 배양 후 정지기에 해당하는 14 시간 만에 각각 $1 \%$ 씩 첨가하고 24 시간 후에 효소 활성에 미치는 영향을 분석하였다.

\section{시료 준비}

세포 배양액은 원심분리 $(10,000 \times g, 10$ 분 $)$ 하여 상등액은 extracellular의 지질분해효소 활성에 사용하였고, 세포 침전물 은 완충액 (50 mM Tris-HCl (pH 7.5), $25 \mathrm{mM} \mathrm{NaCl}, 25 \mathrm{mM}$ EDTA)에 현탁한 후 초음파 파쇄 하였다. 세포 파쇄액은 원심 분리(16,000×g, 20 분) 하고 상등액과 침전은 각각 intracellular 와 membrane의 효소활성 측정에 사용하였다.

\section{효소 활성 측정}

효소 활성측정은 표준물질로서 $p$-nirtophenyl palmitate를 사용한 colorimetric 방법[21]에 의하여 수행되었다. $p$ -nirtophenyl palmitate (PNPP) $30 \mathrm{mg}$ 을 2-propanol $10 \mathrm{ml}$ 에 녹인 용액과 sodium deoxycholate (Na-DOC) $0.207 \mathrm{~g}$ 및 gum arabic $0.1 \mathrm{~g}$ 을 $50 \mathrm{mM}$ sodium phosphate buffer $(\mathrm{pH}$ 6.0) 90 $\mathrm{ml}$ 에 녹인 용액을 혼합하고 혼합한 용액 $2 \mathrm{ml}$ 에 효소액 0.1 $\mathrm{ml}$ 을 가하여 $60^{\circ} \mathrm{C}$ 에서 10 분간 반응한 후 $2 \mathrm{M} \mathrm{Na}_{2} \mathrm{CO}_{3}$ 용액 $0.9 \mathrm{ml}$ 를 가하여 반응을 중지시켰다. 지질분해효소 활성은 생 성된 pnitrophenol의 양을 $410 \mathrm{~nm}$ 에서 측정하였다. 효소 1 unit의 정의는 1 분당 $1 \mathrm{\mu M}$ 의 pnitrophenol을 생산하는 효소 의 양을 나타낸다.

\section{결과 및 고찰}

\section{지질분해효소 생산 균주의 분리 및 동정}

일본 $\mathrm{Beppu}$ 온천지대에서 채취한 시료의 온도는 $72.5^{\circ} \mathrm{C}$ 이
고 $\mathrm{pH}$ 는 6.8 이었다. 시료는 재료 및 방법에서 언급한 것과 같 이 선별하여 한 종류의 균주(AR1)를 얻을 수 있었다. 분리균주 AR1은 호기성으로 고체배지 상에서의 colony 형태는 원형에 가깝고 색깔은 하얀색이었으며 표면은 넙적하고 매끄러운 상 태였다. 이 균주는 그람 양성 간균이고 편모가 없으며 내생포 자를 형성하였다. 분리균주 AR1의 생리적 특징은 Table 1에서 와 같이, 생육가능 $\mathrm{pH}$ 가 5.0 9.0(최적 $\mathrm{pH}$ 6.5)이고 생육가능온 도는 $35 \sim 75^{\circ} \mathrm{C}$ (최적온도 $65^{\circ} \mathrm{C}$ )이며, $\mathrm{H}_{2} \mathrm{~S}$, Urease, tryptophane deaminase 등을 생산하지 않았고, glucose, mannitol, sucrose 와 같은 다양한 당을 이용하여 Bacillus stearothermophilus 균주 [15]와 유사한 특징을 나타내었다. 균주 AR1을 동정하기 위하 여 16s rRNA 염기서열(Genebank accession no. DQ647385)을 분석하고 NCBI의 BLAST program을 이용하여 상동성을 분 석한 결과, Geobacillus sp. Y412MC52와 가장 높은 상동성 (99.7\% identity)을 나타내었고, 생리 및 생화학적 성질이 Geobacillus sp.의 유연균으로 분류되어, 최종적으로 본 균주를 Geobacillus sp. AR1으로 동정하였다(Fig. 1).

\section{$\mathrm{pH}$ 및 온도의 효과}

Geobacillus sp. AR1의 생장 및 효소 생산을 위한 최적 $\mathrm{pH}$ 를 확인하기 위하여 배지의 $\mathrm{pH}$ 를 5.0 9.0의 범위에서 조정하였 고, $65^{\circ} \mathrm{C}$ 에서 24 시간 배양한 후 미생물의 균체량 및 extracellular, intracellular, membrane 시료의 효소 활성을 측정 하였다(Fig. 2). Fig. 2의 결과와 같이 미생물 균체량에 있어서 는 $\mathrm{pH}$ 6.5에서 가장 많은 양을 나타냈고, 높은 $\mathrm{pH}$ 에서는 미생 물 생장이 감소하였다. 반면 효소활성은 $\mathrm{pH}$ 7.0 8.5 범위에서 비교적 높은 활성을 보였고, 그 중 $\mathrm{pH}$ 8.5에서 가장 높은 값을 나타내어 효소 생산을 위한 최적 $\mathrm{pH}$ 는 8.5 로 확인되었다. 따라 서, 본 균주는 $\mathrm{pH}$ 에 대한 미생물의 생장과 효소 생산이 일치하 지 않는 것으로 나타났다. 또한 효소 활성의 약 $90 \%$ 는 extracellular에 위치하여 생산된 효소의 대부분이 세포 밖으로 분비된다는 것을 알 수 있었다. 효소 생산을 위한 최적 온도를 측정하기 위하여 미생물을 $50 \sim 70^{\circ} \mathrm{C}$ 에서 배양한 후 균체량과

Table 1. Biochemical characteristics of the strain AR1

\begin{tabular}{lcll}
\hline Optimum temperature & $65^{\circ} \mathrm{C}$ & Indole production & - \\
\hline Optimum $\mathrm{pH}$ & 6.5 & Acetoin production & + \\
Pigmentation & White & Gelatinase & + \\
Growth at/in & & Glucose & + \\
Beta-galactosidase & + & Mannitol & + \\
Arginine dihydrolase & - & Inositol & + \\
Lysine decarboxylase & - & Sorbitol & + \\
Ornithine decarboxylase & - & Rhamnose & + \\
Citrate utilization & - & Sucrose & + \\
$\mathrm{H}_{2}$ S production & - & Melibiose & + \\
Urease & - & Amygdalin & + \\
Tryptophane deaminase & - & Arabinose & + \\
\hline
\end{tabular}




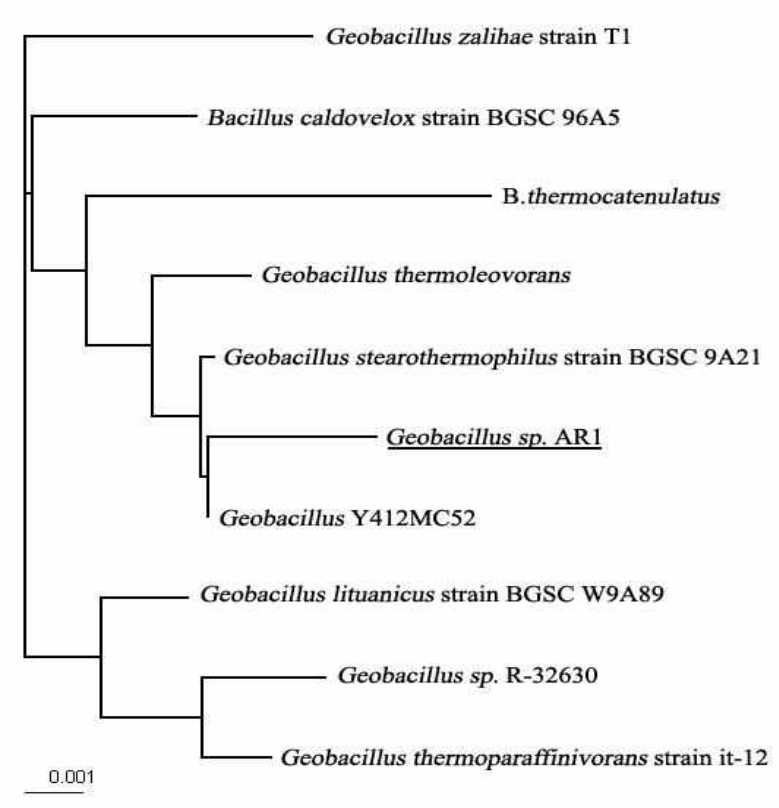

Fig. 1. Phylogenetic position of strain AR1 in the genus Geobacillus based on the 16s rRNA sequences. The tree was constructed using the neighbor-joining method. The bar represents $0.001 \%$ sequence divergence.

효소 활성을 측정하였다. 그 결과 $65^{\circ} \mathrm{C}$ 에서 가장 빠른 미생물 생장과 높은 효소 활성을 보여 효소 생산을 위한 최적 온도는 $65^{\circ} \mathrm{C}$ 로 나타났다(data not shown). 본 균주의 지질분해효소 생산을 위한 최적 $\mathrm{pH}$ 와 온도를 다른 균주와 비교하면, Staphylococcus sp. (최적 $\mathrm{pH} 8.0$, 최적온도 $55^{\circ} \mathrm{C}$ ) 및 T. thermophilus $\mathrm{HB} 27$ (최적 $\mathrm{pH} 7.5$, 최적온도 $70^{\circ} \mathrm{C}$ )과는 차이점을 보였 다 $[3,5]$.

\section{효소 생산을 위한 지질 화합물의 효과}

Geobacillus sp. AR1의 지질분해효소 생산을 위하여 각종 지질 화합물의 영향을 조사하였다. 각종 지질 화합물(olive oil, sesame oil, sunflower oil, soybean oil, grapeseed oil, canola oil, lard oil, 및 tributyrin)을 배지에 최종 농도가 $1 \%$ 가 되게 첨가하고 $65^{\circ} \mathrm{C}$ 에서 24 시간 배양한 후 시료를 취하여 균체량과 효소 활성을 측정하였다. 지질분해효소의 활성 측정 결과, soybean oil을 첨가한 시료가 가장 활성이 높았고, 다른 지질 화합물에서는 대조구와 비슷하거나 낮은 활성을 나타내어 효 소 생산에 큰 영향을 미치지 않았다(Fig. 3). 한편, 균체량은 canola oil이 가장 낮았고 다른 것들은 대조구와 비슷하거나 조금 작은 양을 나타내어 각종 지질 화합물은 미생물 생장에 있어서 별다른 영향을 미치지 않는 것으로 나타났다. 한편, oleic acid와 olive oil는 Candida rugosa의 지질분해효소 유전 자의 발현을 유도하는 것으로 보고 되었고[11], 또한 olive oil 과 sunflower oil은 T. thermophilus HB27의 지질분해효소 생산 을 유도하는 것으로 보고 된 바[5], 본 균주의 지질분해효소
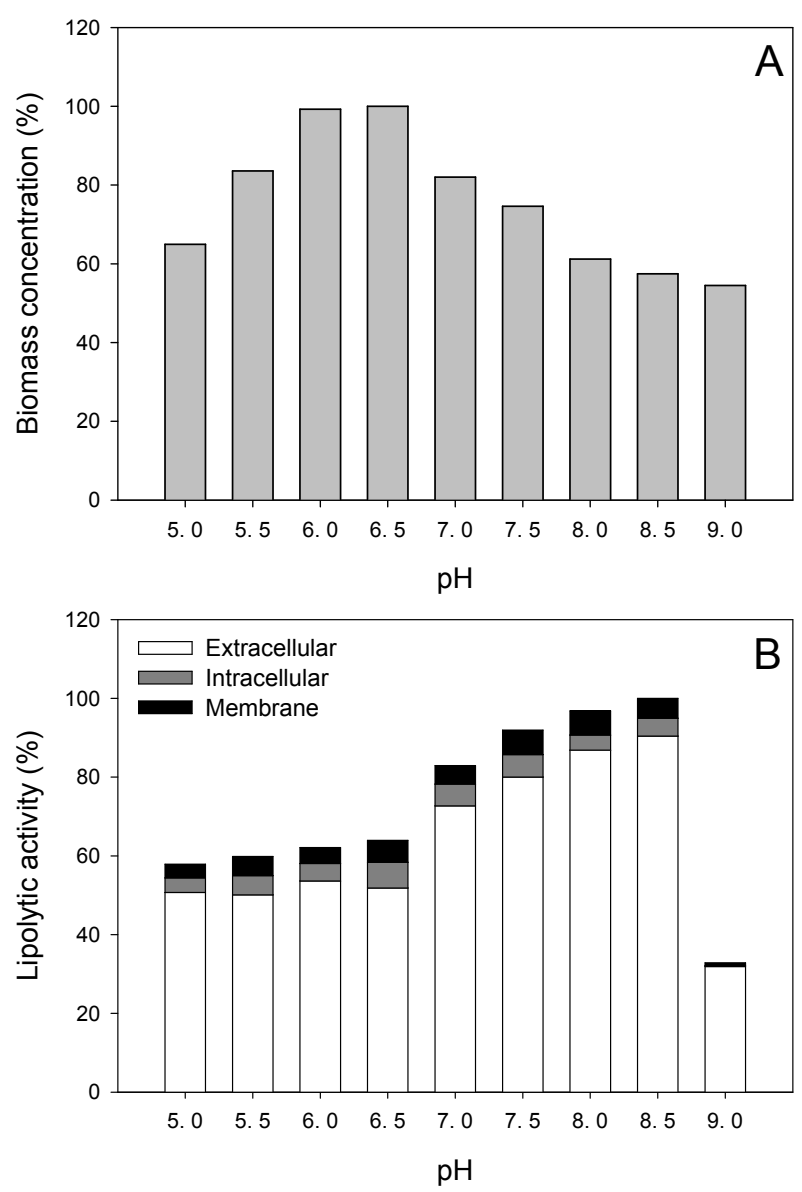

Fig. 2. Effect of initial $\mathrm{pH}$ culture medium on biomass concentration (A) and lipolytic activity (B) of Geobacillus sp. AR1. The values are shown in percentage of the maximum values.

유도물질과는 차이점을 보였다.

\section{지질 화합물의 첨가 시간에 대한 효과}

Cherif 등에 의하면 미생물 배양 중에 oleic acid를 첨가할 경우, 첨가한 시간에 따라 미생물의 생장률과 extracellular 효 소의 활성에 영향을 미치는 것으로 보고 하였다[3]. 본 균주에 대해서도 이와 같은 효과를 알아 보기 위하여, soybean oil을 배양 시작시점(0시간), 대수증식기의 시작시점(5시간), 대수증 식기의 종료시점(10시간)에 각각 첨가하고, 24 시간까지 배양 하여 시료의 지질분해효소 활성을 측정하였다. 그 결과 지질 분해효소 활성은 soybean oil을 배양 시작시점에 첨가한 것보 다 5 와 10 시간 만에 첨가해 준 것이 더욱 높은 효소 활성을 나타내었고, 특히 intracellular와 membrane의 효소 활성이 비 교적 많이 증가한 것으로 나타났다(Fig. 4). 따라서 지질분해효 소 생산을 향상 시키기 위해서는 soybean oil을 배양 초기에 첨가하는 것보다 대수증식기에 첨가하는 것이 더욱 효과적인 것으로 확인되었다. 

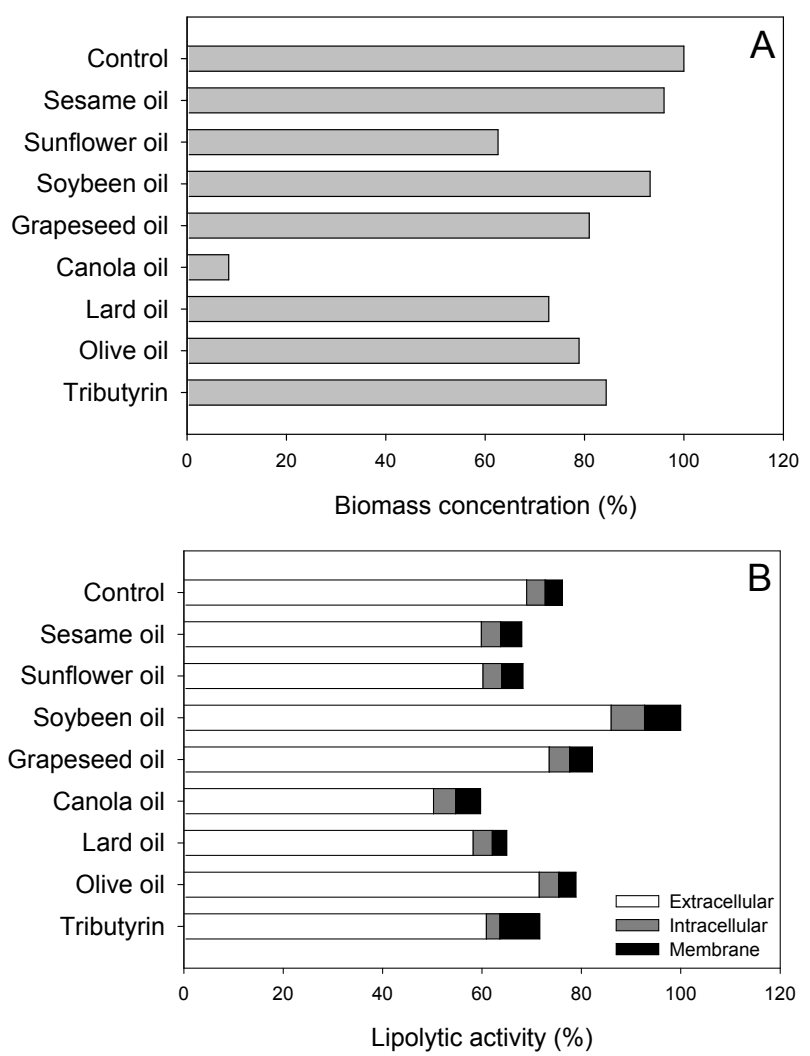

Fig. 3. Influence of the presence of different lipid compounds on biomass concentration (A) and lipolytic activity (B) of Geobacillus sp. AR1. The values are shown in percentage of the maximum values.

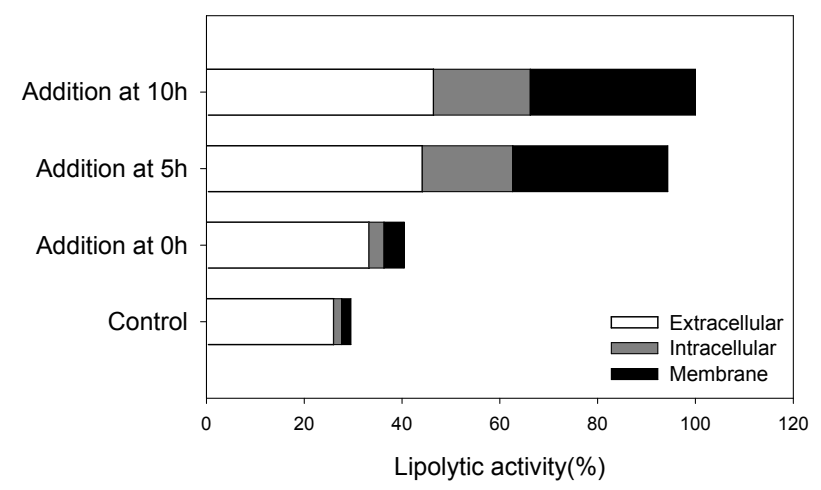

Fig. 4. Effect of the time of addition of soybean oil on the lipolytic activity of Geobacillus sp. AR1. The data of lipolytic activity was taken after $24 \mathrm{hr}$ of growth and shown in percentage of the maximum values.

\section{효소 생산을 위한 계면활성제의 효과}

지질분해효소의 세포 외 분비 생산을 위한 유도물질로서 Tween 80은 Aspergillus terreus, Candida cylindracea 및 Serratia marescens $[9,10,16]$ 의 효소 생산을 유도하였고, Triton X-100 은 Hendersonula torulaidea 및 A. terreus [10,17]의 효소 생산을 유도하는 것으로 보고 되었다. 반면에 Pseudomonas pseudoalca-

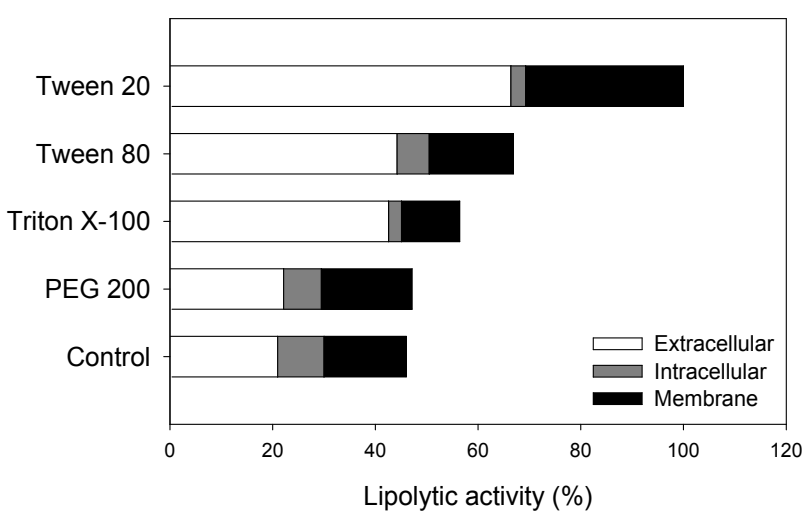

Fig. 5. Effect of the addition of surfactant after $16 \mathrm{hr}$ on the lipolytic activity of Geobacillus sp. AR1. The data of lipolytic activity was taken after $24 \mathrm{hr}$ of growth and shown in percentage of the maximum values.

ligenes F-111 균의 경우 Tween 80과 Triton X-45의 첨가로 인 하여 효소 생산이 완전히 저해되는 것으로 보고 된 바 있다 [14]. 본 균주에 대해서 4 가지 다른 종류의 계면활성제(Tween 20, Tween 80, Triton X-100, PEG 200)를 배양 중 정지기(14 시간)에 첨가하고 24 시간 동안 배양한 후, 각 시료에 대한 효소 활성을 측정하였다. Fig. 5에서와 같이 PEG 200을 제외한 다른 계면활성제를 첨가한 경우, 대조구 보다 효소 활성이 향상 되 었고, 특히 Tween 20을 첨가한 경우, extracellular와 membrane의 효소 활성이 크게 증가하여 막 결합 단백질의 양과 세포 외로 분비되는 효소량이 동시에 증가한 것을 알 수 있었 다. 이와 같은 결과는 T. thermophilus HB27 [5]에서 보고된 바와 같이, 계면활성제가 세포막의 단백질과 지질 성분을 가 용화 하여 세포막이 일부 파괴되고 세포 내부의 효소가 방출 되어 extracellular의 효소량이 증가하는 것으로 추정된다. 한 편, 계면활성제를 유도기 또는 대수증식기에 첨가한 경우에는 세포 증식이 억제되어 효소 활성이 거의 나타나지 않았다 (data not shown). 이와 같이 extracellular 지질분해효소의 최 대 생산량을 얻기 위해서는 soybean oil과 Tween 20을 각각 대수증식기와 정지기에 첨가하는 것이 가장 효율적인 것으로 확인 되었다.

\section{지질 화합물과 계면활성제의 첨가에 따른 효과}

앞서 확인된 결과에서와 같이, soybean oil과 Tween 20을 각각 대수증식기(5 시간)와 정지기(14 시간)에 첨가하고, 각 시간 별로 시료를 채취하여 균체량 및 효소 활성을 대조구와 비교하였다. 그 결과 soybean oil을 첨가한 후에 균체량과 전 체 효소 활성이 대조구와 비교하여 크게 증가하는 것을 알 수 있었다(Fig. 6). 반면, Tween 20을 첨가한 후에는 균체량과 전체 효소 활성이 크게 감소하였다. 그러나, 전체 효소 활성 중에서 membrane의 효소 활성이 크게 감소하는 대신에 extracellular 의 효소 활성은 현저하게 증가하는 것으로 나타났 


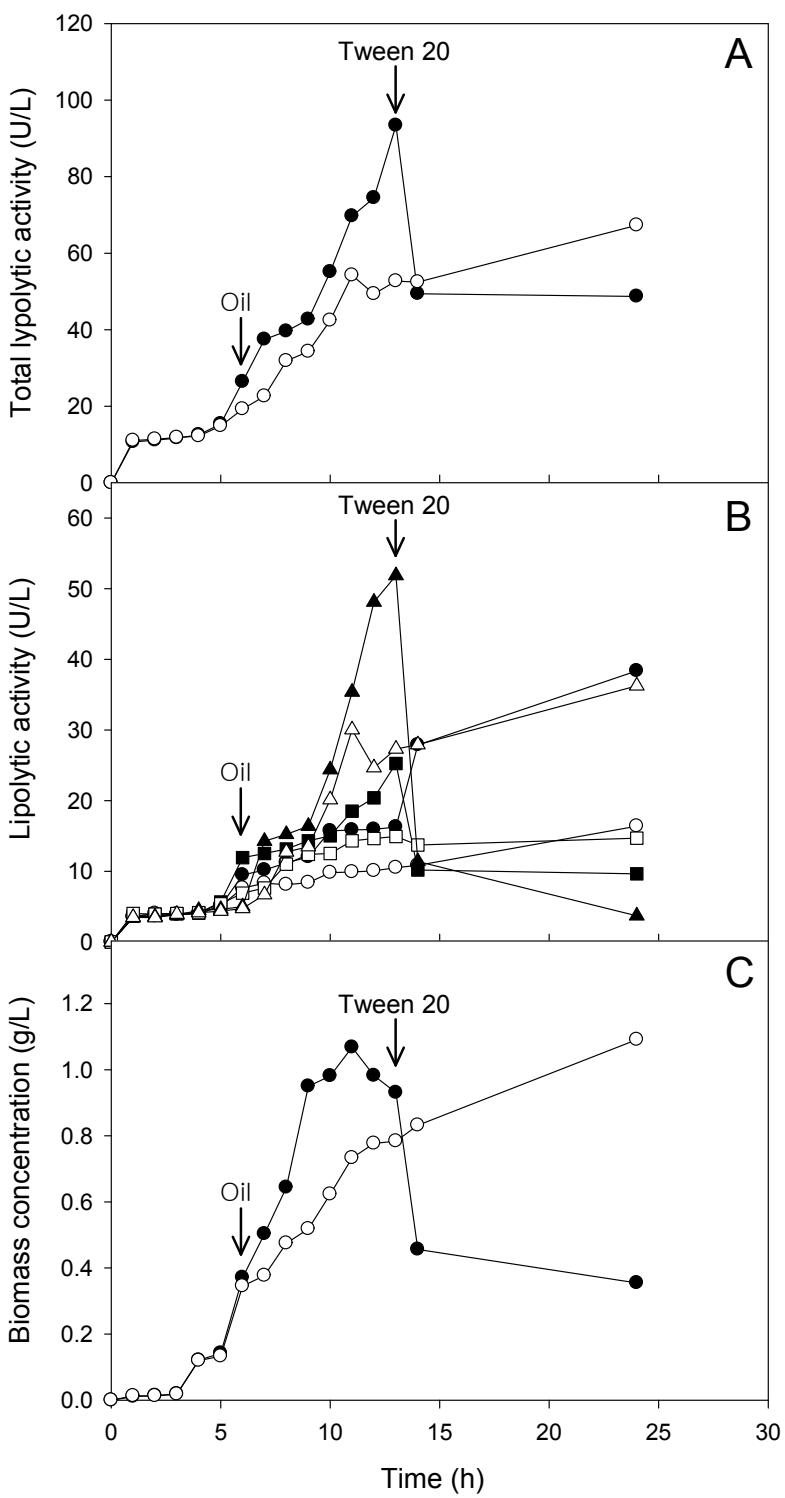

Fig. 6. Effect of the joint addition of soybean oil and Tween 20 on biomass concentration and lipolytic activity of Geobacillus sp. AR1. A: total lipolytic activity. B: extracellular $(\mathbf{O}, \bigcirc)$; intracellular $(\boldsymbol{\square}, \square)$ and membrane $(\boldsymbol{\Lambda}, \triangle)$ lipolytic activity. C: Biomass concentration. In all figures, the values obtained in cultures with and without soybean oil and Tween 20 are represented by full and void symbols, respectively. Data represent duplicate experiments.

다(Fig. 6). 따라서, 본 균주의 배양 중에 soybean oil과 Tween 20을 첨가할 경우, extracellular의 효소 생산량은 대조구 보다 약 2.4 배 정도 증가하는 것으로 확인 되었다.

\section{감사의 글}

이 논문은 2011학년도 동의대학교 교내연구비에 의해 연구
되었음(과제번호 2011AA195).

\section{References}

1. Arpigny, J. L. and Jaeger, K. E. 1999. Bacterial lipolytic enzymes: classification and properties. Biochem J343, 177-183.

2. Brockman, H. W., Mornsen, W. E. and Tsuijita, T. 1988. The biology, biochemistry and biotechnology of lipases. $J \mathrm{Am}$ Oil Chem Soc 65, 891-896.

3. Cherif, S., Mnif, S., Hadrich, F., Abdelkafi, S. and Sayadi, S. 2011. Strategy for improving extracellular lipolytic activities by a novel thermotolerant Staphylococcus sp. strain. Lipids Health Dis 10, 1-8.

4. Deive, F. J., Álvarez, M. S., Morán, P., Sanromán, M. A. and Longo, M. A. 2012. A process for extracellular thermostable lipase production by a novel Bacillus thermoamylovorans strain. Bioprocess Biosyst Eng 35, 931-941.

5. Deive, F. J., Carvalho, E., Pastrana, L., Rúa, M. L., Longo, M. A. and Sanroman, M. A. 2009. Strategies for improving extracellular lipolytic enzyme production by Thermus thermophilus HB27. Bioresour Technol 100, 3630-3637.

6. Dominguez, A., Sanroman, A., Fucinos, P., Rua, M. L., Pastrana, L. and Longo, M. A. 2004. Quantification of intraand extra-cellular thermophilic lipase/esterase production by Thermus sp. Biotechnol Lett 26, 705-708.

7. Fucinos, P., Abadin, C. M., Sanroman, A., Longo, M. A., Pastrana, L. and Rua, M. L. 2005. Identification of extracellular lipases/esterases produced by Thermus thermophilus HB27: Partial purification and preliminary biochemical characterization. J Biotechnol 117, 233-241.

8. Fucinos, P., Dominguez, A., Sanroman, M. A., Longo, M. A., Rua, M. L. and Pastrana, L. 2005. Production of thermostable lipolytic activity by Thermus species. Biotechnol Prog 21, 1198-1205.

9. Gao, L., Xu, J. H., Li, X. J. and Liu, Z. Z. 2004. Optimization of Serratia marcescens lipase production for enantioselective hydrolysis of 3-phenylglycidic acid ester. J Ind Microbiol Biotechnol 31, 525-530.

10. Gulati, R., Saxena, R. K., Gupta, R., Yadav, R. P. and Davidson, W. S. 2000. Parametric optimisation of Aspergillus terreus lipase production and its potential in ester synthesis. Process Biochem 35, 459-464.

11. Hsu, K. H., Lee, G. C. and Shaw, J. F. 2008. Promoter analysis and differential expression of the Candida rugosa lipase gene family in response to culture conditions. J Agric Food Chem 56, 1992-1998.

12. Kim, D. J., Morikawa, M., Takagi, M. and Imanaka, T. 1995. Gene cloning and characterization of thermostable peptidyl prolyl cis-trans isomerase (PPIase) from Bacillus stearothermophilus. J Ferment Bioeng 79, 87-94.

13. Kwon, D. Y. and Rhee, J. S. 1986. A simple and rapid colorimetric method for determination of free fatty acids for lipase assay. JAOCS 63, 89-92.

14. Lin, S. F., Chiou, C. M. and Tsai, Y. C. 1995. Effect of Triton X-100 on alkaline lipase production by Pseudomonas pseu- 
doalcaligenes F-111. Biotechnol Lett 17, 959-962.

15. Logan, N. A. and Berkeley, R. C. 1984. Identification of Bacillus strains using the API system. J Gen Microbiol 130, 1871-1882.

16. Muralidhar, R. V., Chirumamila, R. R., Marchant, R. and Nigam, P. 2001. A response surface approach for the comparison of lipase production by Candida cylindracea using two different carbon sources. Biochem Eng J 9, 17-23.

17. Odibo, F. J. C., Okereke, U. O. and Oyeka, C. A. 1995. Influence of culture conditions on the production of lipase of Hendersonula toruloidea. Bioresour Technol 54, 81-83.

18. Santos, M. A., Williams, R. A. D. and da Costa, M. S. 1989. Numerical taxonomy of Thermus isolated from hot springs in Portigal. Syst Appl Microbiol 12, 310-315.

19. Sekhon, A., Dahiya, N., Tiwari, R. P. and Hoondal, G. S. 2005. Properties of a thermostable extracellular lipase from Bacillus megaterium AKG-1. J Basic Microbiol 45, 147-154.

20. Sharma, R., Chisti, Y. and Banerjee, U. C. 2001. Production, purification, characterization, and applications of lipases. Biotechnol Adv 19, 627-662.

21. Stuer, W., Jaeger, K. E. and Winkler, U. K. 1986. Purification of extracellular lipase from Pseudomonas aeruginosa. $J$ Bacteriol 168, 1070-1074.

22. Sugihara, A., Tani, T. and Tominaga, Y. 1991. Purification and characterization of a novel thermostable lipase from Bacillus sp. J Biochem 109, 211-215.

초록 : 신규 고온성 Geobacillus sp. AR1의 extracellular 지질분해효소 생산을 위한 배양조건

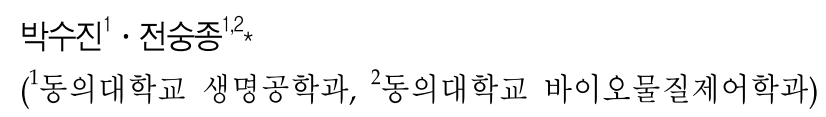

Extracellular 지질분해효소를 생산하는 균주 AR1은 일본 벳부 온천수에서 분리하였다. 분리된 균주의 $16 \mathrm{~s}$ rRNA 염기서열을 분석하고 계통학적으로 분류한 결과, AR1 균주는 신규 Geobacillus sp.에 속하는 것으로 동정되 었다. 본 연구는 Geobacillus sp. AR1 균주의 extracellular 지질분해효소 생산을 향상시키기 위한 새로운 방법에 초점을 맞추었다. $\mathrm{AR} 1$ 균주는 $35 \sim 75^{\circ} \mathrm{C}$ 의 넓은 온도 범위에서 생육하였고 최적온도는 $65^{\circ} \mathrm{C}$ 이었다. 생육을 위한 최적 $\mathrm{pH}$ 는 6.5 인 반면, 효소 생산을 위한 $\mathrm{pH}$ 는 8.5 로 차이점을 보였다. 배양 중에 지질 화합물의 첨가는 지질분해 효소 생산을 유도하였고, soybean oil을 대수증식기에 첨가 했을 때 가장 효율적인 유도 효과를 나타내었다. 한편, 계면활성제는 지질분해효소의 생산을 유도하고 세포 내외의 위치에 영향을 줄 수 있다. AR1 균주는 정지기에 Tween 20을 첨가할 경우, 효소의 세포 외 분비 효율이 크게 증가하였다. 이들 결과를 바탕으로 soybean oil과 Tween 20을 각각 대수증식기와 정지기에 첨가함에 따라 extracellular 효소 생산이 대조구에 비해 2.4배 증가하는 것으로 확인 되었다. 